\title{
Politik Hukum yang Berorientasi pada Administrasi Kelautan dan Kemaritiman
}

\author{
Endri \\ Fakultas Ilmu Sosial dan Ilmu Politik, Universitas Maritim Raja Ali Haji \\ Email: endrieshaemha@gmail.com
}

\begin{abstract}
The purpose of this study is to find out the politics of law which is oriented to maritime and maritime administration. The writing method is writing law which is analyzed using qualitative analysis. The results of the research show that legal politics is the direction of development that will be achieved by the Indonesian state. As a state of law and as an archipelago, the legal politics of the Indonesian people are not yet fully oriented towards maritime and maritime affairs. Some regulations which are bound with maritime affairs and maritime affairs are not effective in law enforcement so that they need to be improved or revised but they are not included in the legislation program. While the legislation programs that have been set up, there are still some that have not been achieved, especially regarding maritime affairs and maritime affairs.
\end{abstract}

Keywords: Maritime Administration, Political Law, Indonesia.

Abstrak

Tujuan kajian ini adalah untuk mengetahui politik hukum yang berorientasi pada administrasi kelautan dan kemaritiman. Metode penulisan adalah penulisan hukum yang dianalisis menggunakan analisis kualitatif. Hasil penelitian menjukan bahwa politik hukum merupakan arah pembangunan yang akan dicapai oleh negara Indonesia. Sebagai negara hukum dan sebagai negara kepulauan, politik hukum bangsa Indonesia belum sepenuhnya berorientasi pada kelautan dan kemaritiman. Beberapa peraturan yang terikat dengan kelautan dan kemaritiman tidak efektif dalam penegakan hukum sehingga perlu perbaikan atau revisi akan tetapi tidak masuk program legislasi. Sedangkan program legislasi yang telah ditetapkan pun masih ada yang belum tercapai khususnya tentang kelautan dan kemaritiman.

Kata Kunci: Administrasi kelautan, Politik Hukum, Indonesia.

\section{A. Pendahuluan}

Politik hukum bangsa Indonesia sangat menentukan arah bangsa yaitu berdasarkan filsafat Pancasila dan UUD 1945. Filsafat Pancasila sebagai suatu pandangan hidup bangsa Indonesia, merupakan suatu kenyataan objektif yang hidup 
dan berkembang dalam masyarakat Indonesia. ${ }^{1}$ Arah dan tujuan yang harus dicapai diantaranya mewujudkan keadilan sosial dan kesejahteraan masyarakat. Untuk mencapai tujuan tersebut dibentuk lah Program Legislasi Nasional yang di dalamnya memuat undang-undang yang akan dibuat oleh Pemerintah bersama Dewan Perwakilan Rakyat Republik Indonesia (DPR RI).

Program Legislasi Nasional yang selanjutnya disebut Prolegnas adalah instrumen perencanaan program pembentukan Undang-Undang yang disusun secara terencana, terpadu, dan sistematis. ${ }^{2}$ Dengan adanya Prolegnas itu akan terlihat citra hukum yang akan dibuat oleh Pemerintah dan Dewan Perwakilan Rakyat (DPR) untuk lima tahun ke depan. Prolegnas dapat dikatakan pemandu atau perencanaan yang matang pembuatan undang-undang lima tahunan, dan di dalam Prolegnas lima tahunan itu diturunkan lagi menjadi Prolegnas prioritas. Prolegnas lima tahunan merupakan daftar undang-undang yang akan dibuat secara garis besar, sedangkan Prolegnas prioritas adalah daftar undang-undang yang utama atau dianggap paling penting yang akan dicapai setiap tahun.

Berdasarkan hal di atas, akan terlihat arah politik hukum yang akan dicapai sekaligus untuk melihat pembangunan yang berorientasi kemana. Sebagaimana diketahui bahwa Indonesia merupakan negara kepulauan yang luas lautannya lebih kurang tiga kali lipat dari luas daratannya, namun seakan selama ini pembangunan lebih berorientasi di darat dibandingkan pembangunan di bidang kelautan dan kemaritiman. Kenyataan Indonesia sebagai negara kepulauan disadari dan dipertegas dalam Pasal 25A Undang-Undang Dasar Tahun 1945 amandemen ke-IV menyatakan bahwa "Negara Kesatuan Republik Indonesia adalah sebuah negara kepulauan yang berciri Nusantara dengan wilayah dan batas-batas dan hak-haknya ditetapkan dengan undang-undang". 3

Ketentuan dalam UUD 1945 tersebut tidak sebatas aturan tetapi harus dilaksanakan. Hal itu dibuktikan dengan adanya kesadaran pemerintah untuk menjadikan Indonesia sebagai poros maritim dan seyogyanya juga harus tergambar dalam politik hukum sebagai arah dalam pembangunan. Khususnya pembangunan di

\footnotetext{
1 Kaelan, Filsafat Pancasila Pandangan Hidup Bangsa Indonesia, Yogyakarta, Paradigma, 2009, hlm. 1

2 Lihat Pasal 1 ayat (9) Undang-Undang Nomor 12 Tahun 2011 tentang Pembentukan Peraturan Perundang-Undangan

${ }^{3}$ Lihat Pasal 25A Undang-Undang Dasar Negara Kesatuan Republik Indonesia Tahun 1945
} 
bidang kelautan dan kemaritiman karena Indonesia merupakan negara kepulauan. Berdasarkan pendahuluan sebagaimana dikemukakan di atas, permasalahan yang diangkat dalam tulisan ini adalah Apakah politik hukum sudah berorientasi pada kelautan dan kemaritiman?

\section{B. Pembahasan}

Menurut Moh. Mahfud MD, politik hukum adalah arahan atau garis resmi yang dijadikan dasar pijak dan cara untuk membuat dan melaksanakan hukum dalam rangka mencapai tujuan bangsa dan negara. Dapat juga dikatakan bahwa politik hukum merupakan upaya menjadikan hukum sebagai proses pencapaian tujuan negara. ${ }^{4}$ Dengan demikian, arah dalam membuat dan melaksanakan hukum akan terlihat jelas sebagai prioritas pembangunan nasional yang ditetapkan yang harus dicapai. Untuk pencapaian itu diperlukan target dalam pembuatan hukum dalam kurun waktu tertentu.

Pada kesempatan lain Moh. Mahfud MD mengemukakan, bahwa politik hukum adalah legal policy tentang hukum yang akan diberlakukan atau tidak diberlakukan untuk mencapai tujuan negara. Di sini hukum diposisikan sebagai alat untuk mencapai tujuan negara. ${ }^{5}$ Hukum di jadikan sebagai alat untuk mencapai tujuan pembangunan nasional yang sesungguhnya adalah sesuatu yang wajar karena bangsa Indonesia negara hukum. Hal itu sesuai dengan UndangUndang Dasar 1945 di dalam Pasal 1 ayat (3) dijelaskan bahwa negara Indonesia adalah negara hukum. Dampaknya adalah seluruh pembangunan harus di bingkai dalam sistem pembangunan hukum nasional yang hal ini terlihat Program Legislasi Nasional (Prolegnas).

Pembahasan politik hukum untuk mencapai tujuan negara dengan satu sistem hukum nasional mencakup sekurang-kurangnya hal-hal sebagai berikut ${ }^{6}$ :

1. Tujuan negara atau masyarakat Indonesia yang diidamkan sebagai orientasi politik hukum, termasuk penggalian nilai-nilai dasar tujuan negara sebagai pemandu politik hukum;

\footnotetext{
4 Moh. Mahfud MD, Membangun Politik Hukum, Menegakkan Konstitusi, Jakarta, RajaGrafindo Persada Persada, 2012, hlm. 15-16

${ }^{5}$ Moh. Mahfud MD, Politik Hukum di Indonesia, Jakarta, RajaGrafindo Persada,2011, hlm.2

${ }^{6}$ Moh. Mahfud MD, Membangun Politik Hukum, Menegakkan Konstitusi, Op.Cit,... hlm. 16
} 
2. Sistem hukum nasional yang diperlukan untuk mencapai tujuan itu serta faktor-faktor yang mempengaruhinya;

3. Perencanaan dan kerangka pikir dalam perumusan kebijakan hukum;

4. Isi hukum nasional dan faktor-faktor yang mempengaruhi;

5. Pemagaran hukum dengan prolegnas dan judicial review, legislative review, dan sebagainya.

Selanjutnya menurut Bernard L. Tanya ${ }^{7}$, politik hukum mempunyai fungsi ideologis untuk dua hal mendasar: (i) ia memberi titik tolak dan arah dasar bagi tatanan hukum dalam mengelola berbagai persoalan di berbagai bidang demi mencapai tujuan bersama. (ii) ia mengarahkan dan mengerahkan seluruh potensi yang dimiliki hukum untuk mewujudkan tujuan hukum bersama dimaksud.

Tugas politik hukum adalah menciptakan aturan dan sistem implementasi hukum yang menjamin pemerataan anggaran, penghapusan kemiskinan, penyediaan fasilitas publik yang merata, pemberantasan $\mathrm{KKN}$, mendorong sektor ekonomi produktif, atau membuka akses ekonomi lebih besar bagi pelaku ekonomi kecil dan menengah, dan lain sebagainya. ${ }^{8}$

Politik hukum ialah kebijaksanaan dari negara dengan perantaraan badanbadan yang berwenang untuk menetapkan peraturan-peraturan yang dikehendaki, yang diperkirakan bisa digunakan untuk mengekspresikan apa yang terkandung dalam masyarakat dan untuk mencapai apa yang dicita-citakan. ${ }^{9}$ Badan yang berwenang di sini adalah Pemerintah dan DPR yang merumuskan dan merancang Rencana Pembangunan Jangka Panjang (RPJP) Nasional Tahun 2005 - 2025 dan diturunkan dalam Rencana Pembangunan Jangka Menengah (RPJM) Nasional yaitu dibagi lagi yaitu RPJM Nasional I Tahun 2005-2009, RPJM Nasional II Tahun 2010-2014, RPJM Nasional III Tahun 2015-2019, dan RPJM Nasional IV Tahun 2020- $2024^{10}$.

\footnotetext{
${ }^{7}$ Bernard L. Tanya, Politik Hukum Agenda Kepentingan Bersama, (Yogyakarta, Genta Publishing, 2011), hlm. 4-5

${ }^{8}$ Ibid, hlm. 8

9 Sudarto, Hukum Pidana dan Perkembangan Masyarakat Kajian Terhadap Pembaharuan Hukum Pidana, Bandung, Sinar Baru, 1983, hlm. 93

${ }^{10}$ Lihat Pasal 1 ayat (1) dan (3) Undang-Undang Nomor 17 Tahun 2007 tentang Rencana Pembangunan Jangka Panjang Nasional Tahun 2005-2025
} 
Secara garis besar arah pembangunan jangka panjang tahun 2005-2025 terlihat dalam Undang-Undang Nomor 17 Tahun 2007 tentang Rencana Pembangunan Jangka Panjang Nasional Tahun 2005-2025, yaitu ${ }^{11}$ :

1. Mewujudkan masyarakat yang berakhlak mulia, bermoral, beretika, berbudaya dan beradab;

2. Mewujudkan bangsa yang berdaya-saing; Membangun sumber daya manusia yang kualitas; Memperkuat perekonomian domestik dengan orientasi dan berdaya saing global; Penguasaan, pengembangan dan pemanfaatan ilmu pengetahuan dan teknologi; Sarana dan prasarana yang memadai; Reformasi hukum dan birokrasi

3. Mewujudkan Indonesia yang demokratis berlandaskan hukum

4. Mewujudkan Indonesia yang aman dan damai

5. Mewujudkan pembangunan yang lebih merata dan berkeadilan

6. Mewujudkan Indonesia yang asri dan lestari

7. Mewujudkan Indonesia menjadi negara kepulauan yang mandiri, maju, kuat dan berbasiskan kepentingan nasional

8. Mewujudkan Indonesia yang berperan aktif dalam pergaulan Internasional. Berdasarkan hal di atas bahwa RPJM dikonkritkan lagi menjadi Program Legislasi Nasional (Prolegnas). Prolegnas yang sudah berjalan yaitu dari 20152019 terdiri 182 Rancangan Undang-Undang (selanjutnya disebut RUU) dan 13 RUU Prolegnas Kumulatif. ${ }^{12}$ Berdasarkan hal ini terlihat produk hukum apa saja yang di buat selama lima tahun yaitu tahun 2015-2019. Dari sekian Prolegnas bisa diusulkan oleh Pemerintah, DPR atau DPD, juga bisa secara bersama-sama. Dari 182 RUU dan 13 RUU kumulatif Prolegnas dalam rentan waktu 2015-2019 dibagi lagi Prolegnas prioritas.

Prolegnas di samping bertujuan membentuk hukum untuk mencapai tujuan negara tetapi juga bisa mengukur kinerja DPR di bidang program legislasi. Sebagaimana diketahui tugas utama DPR adalah di bidang anggaran, pengawasan dan legislasi. Misalnya Prolegnas prioritas tahun 2018 sebanyak 50 RUU. Namun

\footnotetext{
11 Lihat Lampiran Undang-Undang Nomor 17 Tahun 2007 tentang Rencana Pembangunan Jangka Panjang Nasional Tahun 2005-2025, hlm. 45-76

${ }^{12} \mathrm{http} / / / \mathrm{www} . d p r . g o . i \mathrm{~d} / \mathrm{uu} /$ prolegnas-long-list, diakses pada 28 September 2017, jam $13.10 \mathrm{WIB}$
} 
yang berkaitan dengan kelautan dan kemaritiman sebagai salah salah satu arah politik hukum nasional hanya beberapa RUU saja. Antara lain misalnya RUU tentang Wawasan Nusantara (pengusul DPD), RUU tentang Penyelenggaraan Pemerintah di Wilayah Kepulauan (pengusul DPD), dan RUU tentang Perubahan atas Undang-Undang Nomor 1 Tahun 1973 tentang Landasan Kontinen Indonesia (pengusul Pemerintah).

Selanjutnya, suatu produk undang-undang tidak lepas dari dimensi ruang dan waktu dimana undang-undang itu dibuat. Undang-undang yang baik dapat dikatakan hasil dari cerminan masyarakat tersebut, artinya pembentukan undangundang itu berasal dari sosio-politik yang dianut dan budaya serta nilai-nilai masyarakat itu. Dengan demikian, produk hukum yang berupa undang-undang itu tidak muncul begitu saja, yaitu ada historis filosofis yang mendasari pembentukannya. Disamping produk hukum merupakan cerminan rakyat, sebaliknya pemerintah juga mempunyai kebijakan yang direncanakan dan akan diimplementasikan.

Berdasarkan hal itu, politik hukum bangsa Indonesia juga tidak lepas dari keyakinan masyarakat dan geografis wilayah suatu bangsa. Pembangunan akan mengalami hambatan apabila tidak berlandaskan nilai dan geografis tersebut. Wilayah Indonesia yang terdiri dari ribuan pulau tentu pengaturannya akan berbeda dengan wilayah suatu negara yang tidak memiliki pantai. Dengan demikian, sangat logis gagasan poros maritim dalam rancangan undang-undang seharusnya tergambar dalam setiap produk hukum yang akan dibuat dan sebagai bentuk komitmen pembangunan negara Indonesia yang faktanya negara kepulauan. Apalagi pemerintah sendiri telah menggagas dan menjalankan tentang poros maritim ini yang akan di nilai oleh masyarakat.

Seolah kita sudah taken for granted terhadap konsep poros maritim. Namun, hingga saat ini pemerintah belum mampu menerjemahkan gagasan Presiden tersebut dalam bahasa yang muda dipahami publik. Sebagai sebuah gagasan utama Presiden, mestinya gagasan poros maritim bisa menjadi wacana baru tidak saja dikalangan elit tetapi juga rakyat. ${ }^{13}$ Wacana yang baik adalah wacana jelas maknanya, sehingga publik paham dan bisa menaruh harapan. Yang terjadi saat

${ }^{13}$ Arif Satria, Politik Kelautan dan Perikanan, Jakarta, Yayasan Pustaka Obor Indonesia, 2015, hlm. 171 
ini adalah bahwa poros maritim dimaknai secara beragam oleh berbagai pihak sesuai dengan kompetensi, kewenangan dan kepentingannya masing-masing. Mestinya konsep poros maritim itu satu dan seluruh aparat pemerintah memaknainya sama. ${ }^{14}$

Ketika ditanya apa itu poros maritim, makna secara sederhana, maka kita bisa merujuk pada Kamus Besar Bahasa Indonesia. Poros berarti sumbu dan maritim berarti berkenaan dengan laut atau berhubungan dengan perdagangan dan pelayaran di laut. Namun, pengertian maritim yang dimaksud Jokowi adalah lebih umum dari sekedar pelayaran. Dengan demikian poros maritim dunia adalah pusat kekuatan maritim yang disegani di dunia yang mampu menjadikan sumber daya laut sebagai pilar pembangunan nasional baik secara ekonomi, sosial budaya, maupun pertahanan. ${ }^{15}$ Fakta geografis menunjukkan Indonesia merupakan negara kepulauan, karena Indonesia memiliki lebih dari 17 ribu pulau. Namun fakta ekonomi menunjukkan Indonesia belum menjadi negara maritim karena kita belum mampu mendayagunakan potensi kelautan sebagai pilar ekonomi nasional. ${ }^{16}$ Adapun arah kebijakan hukum yang akan dibangun dalam bidang kelautan dan kemaritiman yang menjadi tantangan dan sekaligus harapan yaitu sebagai berikut:

1) Illegal fishing.

Harus diakui bahwa implementasi penegakan hukum yang sudah di buat pada priode sebelumnya terlihat cukup baik. Khususnya di bidang kemaritiman dan kelautan, misalnya penegakan hukum di bidang perikanan (illegal fishing) berupa penenggelaman atau pembakaran kapal. Hal ini berdampak besar pada sumber daya ikan di laut, yaitu tersedianya sumber daya ikan yang cukup dan terpeliharanya ekosistem ikan di laut. Namun dilihat dari sanksi pidana dalam beberapa putusan Pengadilan Perikanan cenderung diputus ringan dan dampaknya tidak memberikan efek yang begitu besar kepada pelaku walaupun kapalnya ditenggelamkan. Masalah lain dalam illegal fishing adalah instansi yang berwenang melakukan

\footnotetext{
${ }^{14}$ Ibid.

${ }^{15}$ Ibid, hlm.171-172

${ }^{16}$ Ibid, hlm. 172
} 
penindakan pada kasus illegal fishing cukup beragam, dan bisa memperlambat penegakan hukum.

2) Kepentingan nelayan.

Di beberapa kasus, nelayan kecil cenderung menjadi korban dari pemilik modal yang mendirikan tempat wisata bahari atau ekowisata, dan mengancam aktifitas nelayan untuk mencari ikan di wilayah tersebut. Nelayan puluhan tahun mencari ikan dan hidup di wilayah itu tiba-tiba dilarang dengan alasan tindak memiliki bukti-bukti kepemilikan tanah/wilayah tersebut. Dengan demikian, pemerintah pusat maupun daerah perlu menjamin hak atas tanah yang ditempati di pinggiran pantai atau pulau kecil lainnya. Dengan demikian, berbicara politik hukum merupakan bagian intergral dari kebijakan sosial ("social policy") di samping kebijakan kesejahteraan social ("social welfare policy”) dan kebijakan perlindungan masyarakat ("social defence policy") guna mencapai tujuan tertentu ("goal"). ${ }^{17}$ Dengan demikian, politik hukum untuk mensejahterahkan nelayan dengan menyediakan kawasan penangkapan ikan yang cukup sebagai kebijakan perlindungan masyarakat.

3) Pelabuhan

Tantangan di bidang kemaritiman juga erat kaitannya dengan sarana dan prasarana pelabuhan, baik pelabuhan orang, pelabuhan barang dan pelabuhan ikan. Dengan kebijakan tol laut yang menghubungkan antar pulau sangat memudahkan masyarakat yang tinggal di wilayah kepulauan. Misalnya di Kabupaten Anambas dan Natuna Provinsi Kepulauan Riau, transportasi barang dan orang sangat tergantung dengan kapal. Wilayah pulau-pulau tersebut sebagian belum memiliki pelabuhan yang dapat disinggahi oleh kapal besar, dan masih dilansir dari kapal besar yang berhenti di tengah laut dengan kapal kecil untuk mengakut barang ke daratan. Dampaknya biaya transportasi pengiriman barang masih cukup tinggi.

4) Pertahanan dan Keamanan

${ }^{17}$ Nyoman Serikat Putra Jaya, Politik Hukum, Semarang, BP UNDIP, 2014, hlm.71 
Penyeludupan narkoba, perdagangan orang, perompakan dan pembajakan, penyeludupan barang illegal lainnya marak terjadi di laut dan sangat merugikan. Dilihat dari lembaga yang berwenang melakukan penegakan hukum di laut cukup beragam, antara lain Tentara Nasional Indonesia Angkatan Laut (TNI AL), Bea Cukai, Polisi Air (Polair), Kementerian Perhubungan (Kemenhub), Kementerian Kelautan dan Perikanan (KKP), Badan Keamanan Laut (Bakamla) dan Satgas Illegal Fishing dan sebagainya. Beragamnya lembaga yang berwenang sebagai penegakan hukum di laut ternyata tidak sebanding dengan luasnya lautan Indonesia yang harus dikawal dan ini menjadi kendala tersendiri. Hal itu sebagaimana diketahui bahwa, Negara Kesatuan Republik Indonesia (NKRI) merupakan negara kepulauan (Archipelagic State) terbesar di dunia dengan 17.499 pulau dan luas perairan laut yang mencapai 5,8 juta $\mathrm{km}^{2}$ dan garis pantai sepanjang $\pm 81.000 \mathrm{~km}$. Sebagai negara kepulauan yang sering disebut zamrud di khatulistiwa, Indonesia memiliki konfigurasi unik dan sekaligus amat menantang di samping mempunyai posisi silang yang strategi antara dua benua dan dua samudera. Sehingga dengan posisi geografis demikian menyebabkan laut wilayah Indonesia menjadi alur laut yang sangat penting bagi lalu lintas pelayaran nasional maupun internasional. $^{18}$

Berdasarkan sebagaimana dikemukakan di atas bahwa, politik hukum dalam pembangunan di bidang kelautan dan kemaritiman masih banyak harus dibenahi. Peraturan perundang-undangan yang ada belum dapat diandalkan sebagai sarana pembangunan dan pembaruan masyarakat. Pemikiran tentang hukum sebagai alat pembaruan dalam masyarakat berasal dari Roscoe Pound dalam bukunya yang terkenal "An Introduction to the Philosophy of Law" (1954). ${ }^{19}$ Perubahan-perubahan penting dan mendasar tersebut agaknya membangkitkan dan mendatangkan sejumlah harapan. ${ }^{20}$ Khususnya di bidang kelautan dan kemaritiman yang menjadi salah satu

\footnotetext{
${ }^{18}$ Jurnal Kajian Lemhanas RI, Penataan Pengamanan Wilayah Maritim Guna Memelihara Stabilitas dalam Rangka Menjaga Kedaultan NKRI, Edisi 14, Desember 2012.

${ }^{19}$ Lili Rasjidi dan Ira Thania Rasjidi, Dasar-Dasar Filsafat dan Teori Hukum, Bandung, Citra Aditya Bakti, 2007, hlm. 76

${ }^{20}$ As"ad Said Ali, Negara Pancasila Jalan Kemaslahatan Berbangsa, Jakarta, LP3ES, 2009, hlm. 99-100
} 
arah pembangunan nasional. Hal itu wajar karena Indonesia sebagai negara demokratis dan wujud pengakuan konstitusi bahwa Indonesia negara kepulauan.

Demokrasi merupakan salah satu prinsip dasar penyelenggaraan negara yang dipilih oleh bangsa Indonesia. Demokrasi adalah wujud pengakuan konstitusional bahwa kedaulatan berada di tangan rakyat. ${ }^{21}$ Sajitpto Rahardjo juga mengemukakan bahwa konstitusi tidak dilihat semata-mata sebagai dokumen hukum, melainkan sebagai dokumen atau piagam yang mengandung pergulatan manusia. Dicoba untuk ditelaah bagaimana konstitusi itu mengekspresikan kosmologi bangsa, mengejawantahkan cita-cita, harapan dan mimpi-mimpi tentang pembangunan negara. ${ }^{22}$ Kosmologi bangsa Indonesia yang dikaruniai alam nusantara yang kaya khususnya di bidang kelautan dan kemaritiman menyadarkan pemerintah untuk melindungi dan merawat dengan sebaik-baiknya. Dengan demikian, harapan untuk menumbuhkan kembali budaya bahari yang melihat laut sebagai sesuatu harus disadari dan sangat penting dalam pembangunan bangsa.

Kebudayaan bahari mestinya dicirikan dengan sejauh mana laut mempengaruhi bentuk organisasi sosial, ciri ekonomi, tingkat pengetahuan dan teknologi. Pada jaman Sriwijaya maupun kerajaan Bugis dimana kejayaan sebagai bangsa bahari terwujud, kebudayaan bahari setidaknya dicirikan dengan kuatnya pertahanan laut, masyarakat cosmopolitan dan terbuka serta pemberani, ekonomi perdagangan berbasis laut, pengetahuan dan keterampilan pelayaran, serta teknologi perkapalan. ${ }^{23}$ Mengembalikan kebudayaan bahari di atas harus dengan revolusi dan tak bisa dengan cara-cara biasa (business as asual). Revolusi adalah perubahan yang menyangkut sendi-sendi kehidupan. Ada sejumlah dimensi revolusi kebudayaan bahari yaitu ${ }^{24}$ :

1) Revolusi cara pandang, yakni perubahan cara pandang laut bahwa laut adalah halaman depan dan wilayah kedaulatan yang harus dijaga secara maksimal baik secara ekologis, ekonomis, maupun geopolitik.

\footnotetext{
${ }^{21}$ Jenedjri M. Gaffar, Politik Hukum Pemilu, Jakarta, Konstitusi Press, 2012, hlm.98

${ }^{22}$ Satjipto Rahardjo, Mendudukan Undang-Undang Dasar; Suatu Pembahasan dari Optik Ilmu Hukum Umum, Semarang, BP Undip, 2007, hlm. 8

${ }^{23}$ Op.Cit, Arif Sartria, Politik Kelautan dan Perikanan, hlm. 146

${ }^{24}$ Ibid, hlm. 147-148
} 
2) Revolusi ekonomi, yakni mewujudkan laut sebagai sumber kemakmuran bangsa dan kesejahteraan rakyat yang harus dikelola secara lestari dan adil.

3) Revolusi IPTEK kelautan, yakni memperkuat sistem pendidikan dan penelitian untuk meningkatkan pengetahuan publik tentang kelautan, serta menghasilkan riset-riset unggulan yang menjadi sumber kemandirian IPTEK kelautan.

4) Revolusi kelembagaan, yakni menciptakan tata aturan yang jelas dalam pengelolaan kelautan dan pemanfaatan laut secara organisasi pengelolaan kelautan yang lebih efisien. Sebagai contoh ada 12 kementerian dan lembaga yang bergerak dalam pengawasan di laut yang tentu menimbulkan tumpeng tindih.

\section{Simpulan}

Berdasarkan sebagaimana dikemukakan di atas bahwa politik hukum merupakan arah pembangunan yang akan dicapai oleh negara Indonesia. Sebagai negara hukum dan sebagai negara kepulauan, politik hukum bangsa Indonesia belum sepenuhnya berorientasi pada kelautan dan kemaritiman. Beberapa peraturan yang terikat dengan kelautan dan kemaritiman tidak efektif dalam penegakan hukum sehingga perlu perbaikan atau revisi akan tetapi tidak masuk program legislasi. Sedangkan program legislasi yang telah ditetapkan pun masih ada yang belum tercapai khususnya tentang kelautan dan kemaritiman.

\section{Daftar Pustaka}

Ali, As"ad Said. 2009. Negara Pancasila Jalan Kemaslahatan Berbangsa. Jakarta : LP3ES.

Jenedjri, M. Gaffar. 2012. Politik Hukum Pemilu. Jakarta : Konstitusi Press.

Jurnal Kajian Lemhanas RI Penataan Pengamanan Wilayah Maritim Guna Memelihara Stabilitas dalam Rangka Menjaga Kedaultan NKRI,, Edisi 14, Desember 2012.

Kaelan. 2009, Filsafat Pancasila Pandangan Hidup Bangsa Indonesia. Yogyakarta : Paradigma.

Mahfud MD, Moh. 2011. Membangun Politik Hukum, Menegakkan Konstitusi, Jakarta, Raja Grafindo Persada Persada

Mahfud MD, Moh. 2011. Politik Hukum di Indonesia. Jakarta : RajaGrafindo Persada.

Putra Jaya, Nyoman Serikat. 2014. Politik Hukum. Semarang : Badan Penerbit Universitas Diponegoro. 
Rahardjo, Satjipto. 2007. Mendudukan Undang-Undang Dasar; Suatu Pembahasan dari Optik Ilmu Hukum Umum. Semarang : Badan Penerbit Universitas Diponegoro.

Rahardjo, Satjipto. 2009. Hukum dan Perilaku; Hidup Baik Adalah Dasar Hukum Yang Baik. Jakarta : Kompas.

Rasjidi, Lili dan Rasjidi, Ira Thania. 2007. Dasar-Dasar Filsafat dan Teori Hukum. Bandung : Citra Aditya Bakti.

Satria, Arif. 2015. Politik Kelautan dan Perikanan. Jakarta : Yayasan Pustaka Obor Indonesia.

Sudarto. 1983. Hukum Pidana dan Perkembangan Masyarakat Kajian Terhadap Pembaharuan Hukum Pidana. Bandung : Sinar Baru

Tanya, Bernard L. 2011. Tanya, Politik Hukum Agenda Kepentingan Bersama, Yogyakarta : Genta Publishing.

Undang-Undang Dasar Negara Kesatuan Republik Indonesia Tahun 1945

Undang-Undang Nomor 12 Tahun 2011 tentang Pembentukan Peraturan Perundang-Undangan

Undang-Undang Nomor 17 Tahun 2007 tentang Rencana Pembangunan Jangka Panjang Nasional Tahun 2005-2025 